\title{
n-Hexane Extract of Mangrove Leaves Effect on p21 and Akt 2 Gene Expressions of WiDr Cells
}

\author{
Istiqomah M. A. ${ }^{1 *}$, Hasibuan P. A. Z. ${ }^{1}$, Basyuni M ${ }^{2}$ \\ 1Department of Pharmacology, Faculty of Pharmacy, Universitas Sumatera Utara, Medan, 20155, Indonesia \\ 2Department of Forestry, Faculty of Forestry, Universitas Sumatera Utara, Medan, 20155, Indonesia
}

\begin{abstract}
A B S T R A C T
Objectives: The study aims to examine the anticancer effect of polyisoprenoid of Nypa fruticans, Ceriops tagal, and Rhizophora mucronata leaves in WiDr cells by evaluating the regulation of p21 and Akt 2 gene.

Design: Nypa fruticans, Ceriops tagal, and Rhizophora mucronata leaves were dried and extracted with n-hexane, analyzed the increase or decrease in regulation of p21 gene and Akt 2 expression which was determined the Reverse Transcription Polymerase Chain Reaction (RT-PCR) method.

Interventions: The variable that was intervened in this study was the 3 sample mangrove leaves.

Main outcome measure: The main measurement results in this study were to study $n$-hexane extracts of mangrove leaves able to suppress the expression of $\mathrm{p} 21$ and Akt 2 genes so that cancer cell growth is inhibited.

Results: n-hexane extract of Ceriops tagal leaves was more effective than Nypa fruticans and Rhizophora mucronata, in which there was up-regulated (p21) of 1.19 and down regulated (Akt 2) of 0.78 on colon cancer cells (WiDr). N-hexane extract of mangrove leaves has cancer chemoprevention activity with up-regulated and down-regulated on WiDr cells, in which the sample was more effective than n-hexane extract of Ceriops tagal leaves.

Conclusion: N-hexane extract of mangrove leaves had cancer chemoprevention activity with up-regulated and down-regulated on WiDr cells, in which the sample was more effective than n-hexane extract of Ceriops tagal leaves.
\end{abstract}

Keywords: Rhizophora mucronata, Nypa fruticans, leaves, Ceriops tagal, daun

A R T I C L E I N F O: Received 01 Oct. 2019; Review Completed 25 Nov. 2019; Accepted 07 Dec. 2019; Available online 15 dec. 2019
Cite this article as:

Istiqomah MA, Department of Pharmacology, Faculty of Pharmacy, Universitas Sumatera Utara, Medan, 20155, Indonesia

\section{INTRODUCTION}

$\mathrm{F}$ Tree radicals are highly active and unstable molecules with orbits in which in the outer layer, one electron is unpaired so as it tends to find its electrons by seizing other electrons, so that it is called reactive oxygen species (ROS) ${ }^{1}$. Free radicals tend to look for electrons, causing damage to cells of other molecules that have lost their electrons. Electron uptake causes a free radical chain reaction that is increasing and tends to damage the macro-forming cells, such as proteins, carbohydrates, fats, and DNA. If the gen damage is not too serious, it can still be repaired with the body's immune response system ${ }^{2}$. However, if it cannot be repaired, it can cause cell division to be interrupted. There are even abnormal changes in certain genes in the body to cause cancer. Cancer in Indonesia in 2019 is estimated to increase by $30 \%^{3}$. Free radicals are from the rest of the body's metabolism, lack of fiber food, or from the outside environment (UV light, pollutants) ${ }^{4}$. Efforts to overcome cancer is from a source of free radical antioxidant compounds. There are two types of antioxidants made from 
synthetic and natural ingredients. Natural antioxidants are obtained from extracts of natural ingredients, while synthetic ingredients are from chemical synthesis ${ }^{5}$.

Most genetic changes cause abnormal cell cycles ${ }^{6}$. In normal cells, there is a balance between the proliferation of cell death in regulation through the cell cycle with cellular checkpoints. Before the cell enters the next phase in the cycle, it must go through a checkpoint that decides whether the previous process in this phase has been completed ${ }^{7}$. The cell cycle in the G1 phase is carried out by regulators by cyclin, cyclin-dependent kinase (CDK). Other proteins are CIP/KIP which include p21, p27, and p57 which are bound to the CDK cyclin complex ${ }^{8}$.

Mangrove plants with characteristics that generally grow in areas on the coast of coral, coral covered with thin sand, muddy soil, or sandy soil, receive sufficient water supply from the ground, protected from large waves, and strong tidal currents ${ }^{9}$. Mangroves are not only beneficial to marine forest ecosystems and coastal areas, insecticides, and natural pesticides ${ }^{10}$, but also been beneficial to health in recent years, known as advances in anticancer treatment technology because of the high polyisoprenoid in each mangrove species. The highest anticancer in the world are breast cancer and colon cancer. Thus, the researcher is interested in the p 21 and Akt 2 gene expression in colon cancer (WiDr) in molecules using the RT-PCR method.

\section{MATERIAL AND METHODS}

\section{Material}

All chemicals and reagents were procured from certified suppliers and were of the highest analytical standard. The colon cancer cell (WiDr) was obtained from Laboratory of Parasitology, Universitas Gadjah Mada, Yogyakarta, Indonesia $^{11-12}$.

\section{Sample Preparation and Extraction}

Nypa fruticans, Ceriops tagal and Rhizophora mucronata leaves were collected from Lubuk Kertang mangrove forest,

Table 1. Description for the RT-PCR primers

\begin{tabular}{|l|l|l|l|}
\hline \multicolumn{2}{|l|}{ Genes } & Sequence (5'-3') & Length (bp) \\
\hline \multirow{2}{*}{ p21 } & F : & GCCAGATTTGTGGCTCACTTCG & \multirow{2}{*}{300} \\
\cline { 2 - 3 } & $\mathrm{R}:$ & ACGCTTGGCTCGGCTCTGG & \\
\hline \multirow{2}{*}{ Akt 2} & $\mathrm{~F}:$ & ATGAATGAGGTGTCTGTCATCAAAGAAGGC & \multirow{2}{*}{315} \\
\cline { 2 - 3 } & $\mathrm{R}:$ & TGCTTGAGGCTGTTGGCGACC & \\
\hline \multirow{3}{*}{-actin } & $\mathrm{F}:$ & GCTCCTCCTAAGCGCGAGT & \multirow{2}{*}{100} \\
\cline { 2 - 3 } & $\mathrm{R}:$ & TCATACTCGCTGTCCTGCATTTG & \\
\hline
\end{tabular}

\section{Statistical analysis}

Data were statistically analyzed using one-way ANOVA for density base pair of p21 and Akt 2 genes, then completed
Langkat, North Sumatra Province, Indonesia, in February 2019. The leaves powder $(500 \mathrm{~g})$ of $N$. fruticans, C. tagal and $R$. mucronata were macerated with chloroform: methanol (2: $1, \mathrm{v} / \mathrm{v})$ for 48 hours, as previously reported ${ }^{13}$. The lipid extract of the leaves was saponified at $65^{\circ} \mathrm{C}$ for $1 \mathrm{~d}$ in $86 \%$ ethanol containing $2 \mathrm{M} \mathrm{KOH}$. The non-saponifiable lipids of both mangrove leaves were extracted with hexane, and the organic solvent was evaporated and re-dissolved in hexane ${ }^{14}$. The major polyisoprenoid compounds of both species were dolichol, and polyprenol was not detected.

\section{An Analysis of Gene Expression p21 and Akt 2 in Vitro by RT-PCR}

Total RNA was extracted from the control and cultured cells using the Total RNA Mini Kit (Geneaid) according to the manufacturer's protocol. Total RNA was reverse-transcribed with $1 \mu \mathrm{g}$ random primer and Rever Tra Ace (Toyobo) to produce a cDNA in a total volume of $20 \mu \mathrm{l}$ for $10 \mathrm{~min}$ at 30 ${ }^{\circ} \mathrm{C}, 60 \mathrm{~min}$ at $42{ }^{\circ} \mathrm{C}$, and $5 \mathrm{~min}$ at $99^{\circ} \mathrm{C}$ according to manufacturer's procedure. The resulting cDNA mixture was diluted TE buffer and directly used for the subsequent PCRs.

Semi-quantitative reverse transcription-PCR (RT-PCR) for p21 and Akt 2 genes ${ }^{15-19}$ was examined using $1 \mu \mathrm{L}$ cDNA added to $25 \mu \mathrm{L}$ PCR Master Mix (12.5 $\mu \mathrm{L}$ GoTax Green, 1 $\mu \mathrm{L}$ primer forward and $1 \mu \mathrm{L}$ primer reverse as listed in Table 1, $9.5 \mu \mathrm{L}$ DNase/RNase free water). Semi-quantitative RTPCR was carried out with $35-40$ cycles for $15-30 \mathrm{sec}$ at $94^{\circ} \mathrm{C}$, $45 \mathrm{sec} 94{ }^{\circ} \mathrm{C}$ and for $10 \mathrm{sec}$ at $55-60{ }^{\circ} \mathrm{C}$, with the final extension phase at $72{ }^{\circ} \mathrm{C}$ for $5 \mathrm{~min}$ then stored at $-20^{\circ} \mathrm{C}{ }^{20}$. The semi-quantitative RT-PCR product was observed using $2 \%$ agarose gel and stained with ethidium bromide. The bands were documented using the image scanner Doc XR Gel (Bio-Rad) ${ }^{20-21}$.

with a Post Hoc Test consisting of the Tukey HSD test. The value of $P<0.05$ was chosen as the threshold of statistical significance. 


\section{RESULT AND DISCUSSION}

The results of testing 3 samples of mangrove leaves n-hexane extract using RT-PCR method can be seen on the Figure 1

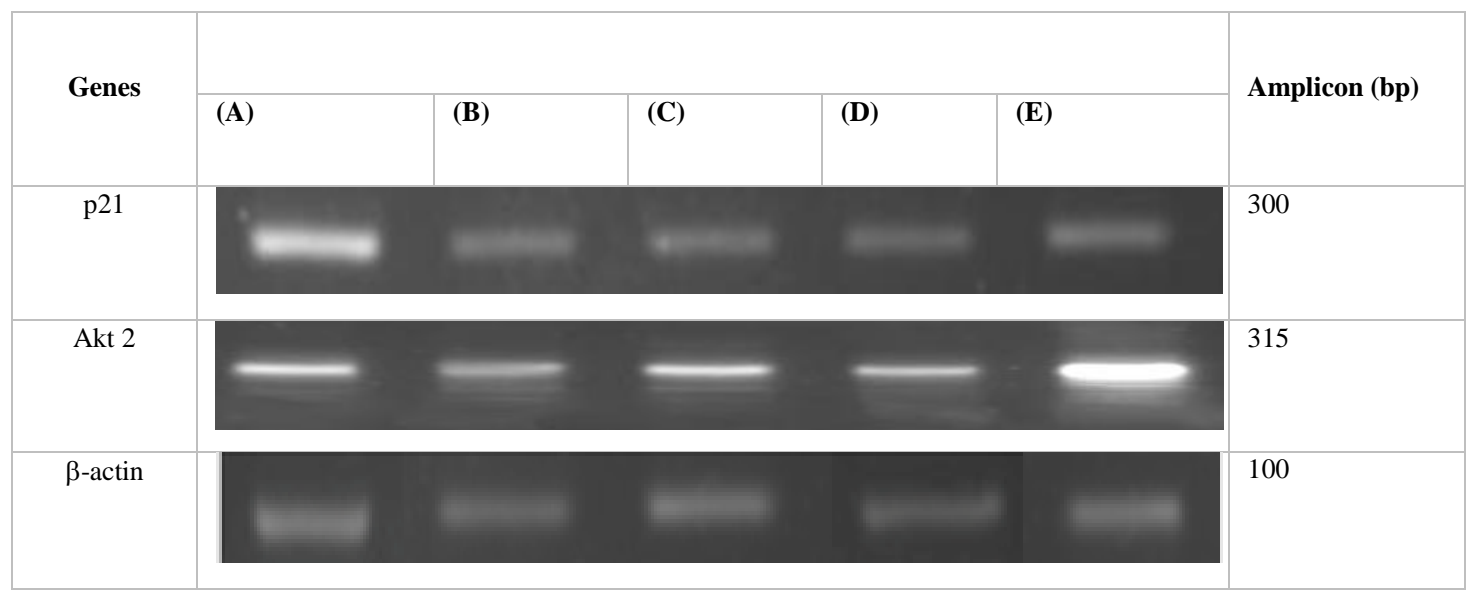

Figure 1. Gene expression of p21, Akt 2 and $\beta$-actin analyzed by RT-PCR method to the treatments of, A: Control cell, B: 5-FU, C: Ceriops tagal, D: Rhizophora mucronata, E: Nypa fruticans

Figure 1 shows the semi-quantitative expression of the p21, Akt 2, and $\beta$-actin genes of Nypa fruticans, Ceriops tagal and Rhizophora mucronata which were analyzed based on base pairs of each gene with RT-PCR. $\beta$-actin as housekeeping gene showed stability expression in cell control, 5-FU as positive control of Nypa fruticans, Ceriops tagal, and Rhizophora mucronata (Figure 1A-E). $\beta$-actin produced an amplification of $100 \mathrm{bp}$. Figure 1A illustrates the p21 expression band with $300 \mathrm{bp}$ of PCR product (300 $\mathrm{bp}$ ), in which 5-FU showed a clear band. On the other hand, Akt 2 was expressed ( $315 \mathrm{bp}$ ) in all the samples tested where the cell control accumulated small band intensities (Figure 1). The $\mathrm{p} 21$ gene as a tumor suppressor gene occurred in all samples with the highest band intensity in the Ceriops tagal.

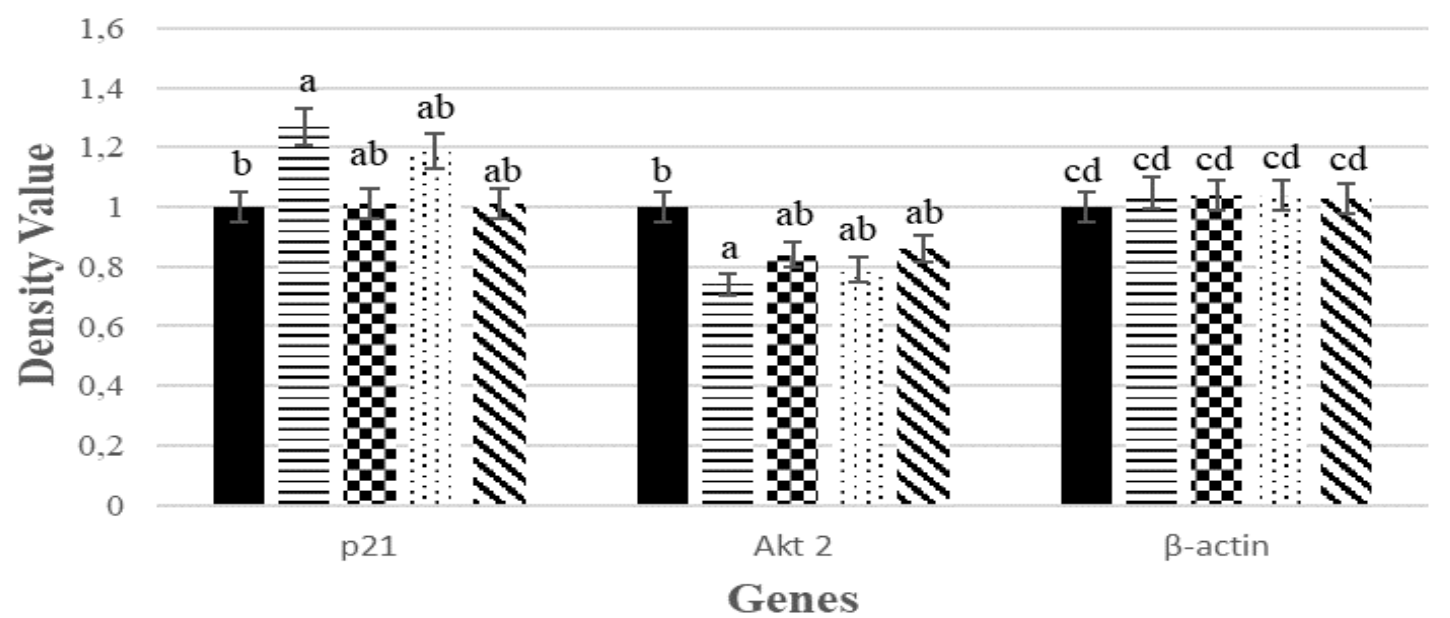

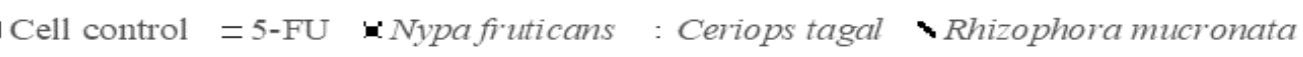

Figure 2. The density value of gene expression evaluated by one Way-Post Hoc Test, Tukey HSD.

$\mathrm{a}=\operatorname{Sig}(P)<0.05$, a statistically significant difference with control cell, $\mathrm{b}=\mathrm{Sig}(P)<0.05$ a statistically significant difference with 5 -FU, $\mathrm{c}=\mathrm{Sig}(P)>0.05$ not a significant difference with cell control,

$\mathrm{d}=\operatorname{Sig}(P)>0.05$ not giving a significant with 5-FU

Figure 2 illustrates the up-regulation and down-regulation values of p21 and Akt 2 gene expression. As p21 is a tumor suppressor gene ${ }^{22}$, it can do an action to prevent the growth of cancer cells and inhibit the development of colon cancer cells. The dolichol content of Ceriops tagal (100\%) showed the most down-regulated results in the Akt 2 gene. In the case of p21, Ceriops tagal was the most effective of Nypa fruticans and Rhizophora mucronata. The value of gene 
expression in Nypa fruticans, Ceriops tagal and Rhizophora mucronata on control cells had a significant difference with $\mathrm{P}<0.05$.

An inverse correlation between $\mathrm{p} 21$ and $\mathrm{p} 53$ expression in colorectal adenocarcinoma has been introduced in a different series, in addition to the direct correlation between advanced disease stage and shorter patient survival with low or absent expression of $\mathrm{p} 21^{23}$. Many recent studies in colorectal carcinoma correlate with high levels of p27 protein with better results ${ }^{24}$. It has been shown that in colorectal carcinoma, loss of $\mathrm{p} 27$ protein is associated with shorter survival and development of metastasis ${ }^{25}$. In other largescale studies, it was found that p21, p27, and p53 are tumor suppressor genes for cell growth ${ }^{26}$.

p21 gene expression has been evaluated as a sign for the efficiency of wild-type of p53 transduction. p21 is a CDK inhibitor, which is the p53 downstream target. In transcriptional, it induces high p53 for DNA decay ${ }^{27}$. p21 acts as a negative regulator of growth during the G1 cell cycle checkpoint which is bound and inhibits cyclin / CDK

\section{REFERENCES}

1. Kawada M, Uehara Y, Mizuno S, Yamori T, Tsuruo T. Upregulation of p27 Kip1 correlates inversely with anchorage independent growth of human cancer cell lines. Jpn J Cancer Res. 1998; 89(2):110-115.

2. Sarioglu S, Sokmen S, Terzi C. Relationship of Angiogenesis and p53 Protein Expression in Colorectal Carcinomas. Colorect Dis. 2001; 3(1):38-41.

3. Toyoshima H, Hunter T. p27, a novel inhibitor of G1 cyclin-Cdk protein kinase activity, is related to $\mathrm{p} 21$. Cell. 1994; 78(1):67-74.

4. Harper JW, Adami GR, Wei N. The p21 Cdk-interacting Protein Cip1 is Potent Inhibitor of G1 cyclin-dependent kinases. Cell. 1993; 75(4):805816.

5. Xiong Y, Hannon GJ, Zhang H. p21 is A Universal Inhibitor of Cyclin Kinases. Nature. 1993; 366:701-704.

6. Polyak K, Lee MH. Erdjument-Bromage. Cloning of p27 Kip1, a cyclindependent kinase inhibitor and a potential mediator of extracellular antimitogenic signals. Cell. 1994; 78:59-66.

7. El-Deiry WS, Harper JW. WAF1/CIP1 is Induced in p53-mediated G1 Arrest and Apoptosis. Cancer Res. 1994; 54:1169-1174.

8. Barbareschi M, Caffo O, Doglioni C. p21 WAF1 Immunohistochemical Expression in Breast Carcinoma: correlation with clinicopathological data, estrogen receptor status, MIB1 expression, p53 gene and protein alterations and relapse-free survival. Br J Cancer. 1996; 74:208-215.

9. Baker SJ, Markowitz S, Fearon SR, Willson JK, Vogelstein B. Suppression of Human Colorectal Carcinoma Cell Growth By Wild Type P53. Science. 1990; 249:912-915.

10. Purnobasuki H. Potensi Mangrove Sebagai Tanaman Obat Prospect of Mangrove as Herbal Medicine. Surabaya. UNAIR. 2004

11. Illian DN, Basyuni M, Wati R, Hasibuan PAZ. Polyisoprenoids from Avicennia marina and Avicennia lanata Inhibit WiDr Cells Proliferation.Phcog Mag. 2018; 14(58):516-518(2018),

12. Sari DP, Basyuni M, Hasibuan PAZ, Wati R. The Inhibition of Polyisoprenoids from Nypa fruticans Leaves on Cyclooxygenase 2 Expression of WiDr Colon Cancer Cells. Asian J Pharm Clin Res. 2018; 11(8):156.

13. Illian DN, Hasibuan PAZ, Sumardi S, Nuryawan A, Basyuni M. Anticancer Activity of polyisoprenoids from Avicennia alba Blume. in WiDr Cells. Iran J Pharm Res. 2019; 18(3):1477-1487.
28. The hypothesis that $\mathrm{p} 21$ is a better mark jet for p53 transduction for tumor cells expressing p53 mutant ${ }^{29}$. As a result, gene 21 expression induced is high both in vitro and in vivo ${ }^{30}$.

\section{CONCLUSION}

This study confirms that the characteristics of Ceriops tagal leaves are more effective than Nypa fruticans and Rhizophora mucronata leaves. The dolichol content of Ceriops tagal provides up-regulation of p21 and down regulation of Akt 2. This study shows that dolichol in Nypa fruticans, Ceriops tagal and Rhizophora mucronata has blocked the growth factor of the colon cancer cell cycle (WiDr).

\section{ACKNOWLEDGEMENT}

This research was funding by Ministry of Research Technology and Higher Education through "Hibah Penelitian Tesis Magister 2018”.

14. Basyuni M, Sagami H, Baba S, Oku H. Distribution and occurrence of new polyprenyl acetone and other polyisoprenoids in Indonesian mangroves. Dendrobiology. 2017; 78:18-31.

15. Nomani A, Fouladdel S, Haririan I, Rahimnia R, Ruponen M, Gazori T, et.al. Poly (amidoamine) dendrimer silences the expression of epidermal growth factor receptor and 553 gene in vitro. Afr J Pharm Pharmacol. 2012; 6(8):530-537.

16. Dong M, Yang G, Liu H, Liu X, Lin S, Sun S, et. al. Aged black garlic extract inhibits HT29 colon cancer cell growth via the PI3K/Akt signaling pathway. Biomed Rep. 2014; 2(2):250-254.

17. Matsumoto K, Arao T, Tanaka K, Kaneda H, Kudo K, Fujita Y, et. al. mTOR signal and hypoxia-inducible factor- $1 \alpha$ regulate CD133 expression in cancer cells. Cancer Res. 2009; 69(18):7160-64.

18. Wang H, Duan L, Zou Z, Li H, Yuan S, Chen X, et. al. Activation of the $\mathrm{PI} 3 \mathrm{~K} / \mathrm{Akt} / \mathrm{mTOR} / \mathrm{p} 70 \mathrm{~S} 6 \mathrm{~K}$ pathway is involved in S100A4-induced viability and migration in colorectal cancer cells. Int J Med Sci. 2014; 11(8):841.

19. Hassan ZK, Elamin MH, Daghestani MH, Omer SA, Al-Olayan EM, Elobeid MA, et. al. Oleuropein induces anti-metastatic effects in breast cancer. Asian Pac J Cancer Prev. 2012; 13(9):4555-4559.

20. Zhang Y, Guan XY, Dong B, Zhao M, Wu JH, Tian XY, et. al. Expression of MMP-9 and WAVE3 in colorectal cancer and its relationship to clinicopathological features. J Cancer Res Clin Oncol. 2011; 138:2035-2044.

21. Kamal, Reddy KS, Khan MN, Shetti RV, Ramaiah MJ, Pushpavalli SN, et. al. Synthesis, DNA-binding ability and anticancer activity of benzothiazole/benzoxazole-pyrrolo $[2,1$-c $][1,4]$ benzodiazepine conjugates. Bioorg Med Chem. 2010; 18(13):4747-61.

22. Kawauchi S, Goto Y, Ihara K, Furuya T, Oga A, Tsuneyoshi M, et. al. Survival Analysis with p27 Expression and Apoptosis Appears to Estimate the Prognosis of Patients with Synovial Sarcoma More Accurately. Cancer. 2002; 94(10):2712-2718.

23. Brissett AE, Olsen KD, Kasperbauer JL, Lewis JE, Goellner JR, Spotts $\mathrm{BE}$, et. al. Merkel cell carcinoma of the head and neck: a retrospective case series. Head Neck. 2002; 24(11):982-988.

24. Ahmed NU, Ueda M, Ichihashi M. p21WAF1/CIP1 Expression in NonMelanoma Skin Tumors. J Cutan Pathol. 1997; 24(4):223-227.

25. Geisler GE, Geisler JP, Miller GA, Geisler MJ, Wiemann MC, Zhou Z, et. al. p21 and p53 in ovarian carcinoma: their combined staining is more valuable than either alone. Cancer. 2001; 92(4):781-786. 
26. Stefanaki K, Rontogiannis D, Vamvouka C, Bolioti S, Chaniotis V, Sotsiou F, et al. Immunohistochemical detection of $\mathrm{BCl} 2, \mathrm{p} 53, \mathrm{mdm} 2$ and p21/waf1 proteins in small-cell lung carcinomas. Anticancer Res. 1998; 18(3A):1689-1695.

27. Barak Y, Juven T, Haffner R, Oren M. MDM 2 Expression is Induced By Wild Type p53 Activity. Embo. J. 1993; 12:461-468.

28. Bischoff JR, Kirn DH, Williams A, Heise C, Horn S, Muna M, et. al. An Adenovirus Mutant That Replicates Selectively in p53 Deficient Human Tumor Cells. Sciences. 1996; 274:373-376.
29. Hasibuan PAZ, Jessy C, Satria D. Combination Effect of Ethylacetate Extracts of Plectranthus ambonicius (Lour.) Spreng with Doxorubicin against T47D Breast Cancer Stem Cells. J Pharm Pharm Sci. 2015; 7:158.

30. Blagosklonny MV, El-Deiry WS. In Vitro Evaluation of a p53Expressing Adenovirus as An Anticancer Drug. Int. J. Cancer. 1996; 67:386-392. 